\title{
Physicochemical Properties, Total Phenolic and Antioxidant Activity of Mixed Tropical Fruit Juice, TP 3 in $1^{\mathrm{TM}}$
}

\author{
Siti Nur Aqilah Abdul Malek ${ }^{1}$, Hasnah Haron ${ }^{1}$, Wan Aida Wan Mustapha ${ }^{2} \&$ Suzana Shahar $^{3}$ \\ ${ }^{1}$ Nutritional Sciences Programme, School of HealthCare Sciences, Faculty of Health Sciences, Universiti \\ Kebangsaan Malaysia, Kuala Lumpur, Malaysia \\ ${ }^{2}$ Food Science Programme, School of Food Science and Technology, Faculty of Science and Technology, \\ Universiti Kebangsaan Malaysia, Bangi, Malaysia \\ ${ }^{3}$ Dietetics Programme, School of HealthCare Sciences, Faculty of Health Sciences, Universiti Kebangsaan \\ Malaysia, Kuala Lumpur, Malaysia \\ Correspondence: Hasnah Haron, Nutritional Sciences Programme, School of Healthcare Sciences, Faculty of \\ Health Sciences, Universiti Kebangsaan Malaysia, Jalan Raja Muda Abdul Aziz, Kuala Lumpur 50300, Malaysia. \\ Tel: 60-392-897-457. Email: hasnaharon@ukm.edu.my
}

$\begin{array}{ll}\text { Received: October 3, } 2017 & \text { Accepted: December 17, } 2017 \quad \text { Online Published: December 31, } 2017 \\ \text { doi:10.5539/jas.v9n13p50 } & \text { URL: https://doi.org/10.5539/jas.v9n13p50 }\end{array}$

This study was funded by Ministry of Science, Technology \& Innovation (MOSTI) Malaysia (e-Science Fund grant, 06-01-02-SF0764).

\begin{abstract}
This study was carried out on the TP 3 in $1^{\mathrm{TM}}$ juice formulation, which consisted of pomegranate concentrate with guava and roselle extract. This study aimed to determine its physicochemical properties, proximate content, total phenolic content, antioxidant activity, total sugar, vitamin $\mathrm{C}$ and several targeted polyphenol compounds. Total phenol content was determined using Folin-Ciocalteu method while antioxidant activity was determined using DPPH and ABTS methods. The results showed $\mathrm{pH}$ and total soluble solid values of the juice were 3.69 and $8.1^{\circ}$ Brix, respectively. The juice has brightness colour of $\mathrm{L}=33.25, \mathrm{a}=3.16$ and $\mathrm{b}=-4.63$. Every $100 \mathrm{ml}$ juice contained $10.92 \mathrm{~g}$ total sugar, $4 \mathrm{mg}$ vitamin $\mathrm{C}$ and $0.44 \%$ titratable citric acid. Proximate analyses showed TP 3 in $1^{\mathrm{TM}}$ juice contained $89.38 \%$ moisture, $0.15 \%$ total ash, $0.16 \%$ protein, $0 \%$ fat and $10.31 \%$ total carbohydrates. The juice was low in calories $(42 \mathrm{kcal} / 100 \mathrm{ml})$ and contained total phenolic $(609 \mathrm{mg}$ GAE$/ 100 \mathrm{ml})$ and total monomeric anthocyanin $(12.94 \mathrm{mg} \mathrm{C} 3 \mathrm{G} / 100 \mathrm{ml})$. Antioxidant value obtained through DPPH and ABTS test methods were $88.90 \%$ and $472.44 \mu \mathrm{M} \mathrm{TE} / \mathrm{ml}$, respectively. Eight selected individual polyphenol compounds ranged from $0.13-633.73 \mathrm{mg} / 100 \mathrm{ml}$ have been identified. TP 3 in $1^{\mathrm{TM}}$ juice consisting three different tropical fruits can be considered of having high phenolic content and antioxidant activity. Consumption of mixed tropical juices with various polyphenol compositions will protect human body from several diseases attributed to the reactions of free radicals.
\end{abstract}

Keywords: pomegranate, guava, roselle, physicochemical, antioxidant

\section{Introduction}

Fruit juices are produced from various parts of plants including flowers and fruits. Different types of fruit juices and drink are available globally and there has been an increased on its consumption due to consumer awareness of nutritional and health benefits. It is well known that natural sources of antioxidants from fruits are more advantageous to health than the synthetic counterparts or supplements (Liu, 2003). Antioxidants are known to have beneficial health promoting properties such as strengthening the body immunity system, reducing the risk of metabolism diseases and delaying the aging process. In fact, this potential health benefits are normally linked to polyphenols activity from plant foods. Polyphenols are also known for its antioxidant characteristics and has been abundantly found in fruits, and other plant sources. Polyphenols as antioxidants may improve cell survival and as pro-oxidants, they may induce apoptosis, prevent tumor growth and other oxidative-stress related disease such as diabetes mellitus (Lambert, Hong, G. Yang, Liao, \& C. S. Yang, 2005). 
Tropical fruits are valuable sources of dietary fiber, vitamins and natural phenolic antioxdant (Mitra, Devi, \& Debnath, 2014). One example of tropical fruits is pomegranate (Punica granatum) under Punicaceae family, a fruit native to the Middle East (Johanningsmeier \& Harris, 2011). Pomegranate is a phytochemical dense fruit containing anthocyanins and hydrolysable tannins (Rasheed et al., 2009). Different parts of this plant are used in indigenous Indian medicine to cure various diseases, particularly diabetes (Jurenka 2008; Medjakovic \& Jungbauer, 2013). Guava (Psidium guajava) fruit is considered as highly nutritious since it contains high levels of ascorbic acid that is three to six times higher than orange (Thaipong, Boonprakob, Crosby, Cisneros-Zevallos, \& Bryne, 2006; Mittal, Gupta, Kaur, Garg, \& Singh, 2010). In another study, it has been reported that guava could be used as a lipid level controller because of its ability to reduce both total cholesterol and low density lipoprotein (LDL) levels in the subjects tested by $18.8 \%$ and $19.4 \%$, respectively, compared to their baseline levels upon consumption for 4 weeks (Rokiah, Fadhillah, Zaitun, \& Asmah, 2003). In additional of having high amount of vitamin C, Hibiscus sabdariffa (Roselle) is one such plant which flowers are used to prepare juices. The roselle extract has a unique red colour, good flavour, low sugar and high acidic content. The acidity makes the juice sour hence the need for addition of sweetening products. Prasongwatana, Woottisin, Sriboonlue, and Kukongviriyapan (2008) reported that its calyx extract of roselle has also been used as an effective treatment for patients with kidney stones due to its uricosuric effect.

Pomegranate is one of the fruit which always mentioned in many health related study while guava and roselle seems to be popular tropical juice enjoyed nowadays. Thus, this study aimed to determine the nutrient compositions in this mixed fruit juices. The synergistic effect from mixing two or more of such fruit juices cannot be over emphasized. The increase or decrease in the content of bioactive compounds or antioxidant activity can be related to chemical reactions that can occur among the fruits, which should be better studied. Thus, the mixture was expected to have acceptable physicochemical quality and have higher phenolic content compared to its single juice. TP 3 in $1^{\text {TM }}$ fruit juice has been patented under UKM Intelectual Property Division and the juice has been used for animal and human studies.

\section{Materials and Methods}

\subsection{Materials}

Chemicals used were comprised of Folin-Ciocalteu's phenol reagent (Switzerland), $( \pm)-6$-Hydroxy-2,5,7,8tetramethylchromane-2-carboxylic acid also known as Trolox (Russian), 2,2-azinobis-3-ethyl-benzothiazoline-6sulfonic acid (ABTS) (Canada), potassium persulfate, 2,2-diphenyl-1-picrylhydrazyl (DPPH), gallic acid (China), ellagic acid (UK), chlorogenic acid (Germany), $p$-coumaric acid, (+)-catechin (France), (-)-epicatechin (France), and procyanidin B2 (France). All chemicals used were Sigma brand.

\subsection{TP 3 in $1^{T M}$ Fruit Juice Preparation}

Pomegranate and guava fruits were cleaned using tap water followed by extraction of juice using heavy duty electric juicer (Breville, Australia) while calyx of the seedless roselle was extracted in hot water for 15 minutes. All fruit extract were mixed and filtered with muslin cloth before it went through low temperature long time (LTLT) pasteurisation process. Finished product were kept in high-density barrier type of bottle and stored in $4-8{ }^{\circ} \mathrm{C}$ prior to analyses. The results for nutrient contents were expressed as the average \pm standard deviation of the two replicates from six batches of finished product.

\subsection{Physicochemical Analysis of Juice}

\subsection{1 $\mathrm{pH}$ Value}

Determination of $\mathrm{pH}$ value for juice was carried out using digital $\mathrm{pH}$ meter. About $15 \mathrm{ml}$ sample was used for the test for each of these samples. The $\mathrm{pH}$ meter (Mettler Toledo, Switzerland) was calibrated before use.

\subsubsection{Total Soluble Solid (TSS)}

Brix value ( ${ }^{\circ}$ Brix) or TSS for all samples has been determined using table-top refractometer (Abbe, Germany) and the lens is adjusted to be midway between the bright and dark side lines.

\subsubsection{Colour Intensitiy}

Approximately $30 \mathrm{ml}$ of homogenized samples was poured into a test tube for measurement using hand-held chromameter (Minolta, Japan). The chromameter was calibrated prior to samples measurement. The test tube has been placed into a special hollow holder in front of the chromameter and the reading was taken for three times to get average value. 


\subsubsection{Vitamin C Content}

Determination of vitamin $\mathrm{C}$ using titration method from the Association of Analytical Communities (AOAC, 2000) was done in this study. Approximately $0.1 \%$ ascorbic acid solution was titrated with $1 \mathrm{ml}$ of $0.01 \%$ DCPIP solution until the original blue color of the DCPIP solution faded. The steps were repeated three times for each sample to get average reading.

\subsubsection{Total Sugar}

Total sugar analysis was done according to International Commision for Uniform Methods of Sugar Analysis (ICUMSA, 2015) method. About $1 \mathrm{ml}$ of $5 \%$ phenol reagent solution was added to $1 \mathrm{ml}$ juice sample which has been diluted for 1000 times. About $5 \mathrm{ml}$ of concentrated $\mathrm{H}_{2} \mathrm{SO}_{4}$ was added slowly into the mixture and was incubated for 30 minutes at room temperature. The mixture absorption was measured at $490 \mathrm{~nm}$ using UV-visible spectrophotometer (Secomam, France). Absorbance of samples was compared with glucose serial dilution $(0.02-0.1 \mathrm{mg} / \mathrm{ml})$ by using standard curve. The amount of total sugar content was reported in $\mathrm{g} / 100 \mathrm{ml}$.

\subsubsection{Titratable Acidity (TTA)}

Titratable acidity of the juice was determined according to Fabro et al. (2006) with some modification. About 10 $\mathrm{ml}$ of the sample was transfered into volumetric flask $(100 \mathrm{ml})$ which was then topped up with distilled water until it reached the volume. About $10 \mathrm{ml}$ solution from the flask was placed into a conical flask and three drops of $2 \%$ phenolphthalein were added into the sample. The sample was then titrated with $0.1 \mathrm{~N} \mathrm{NaOH}$ until the pink color appeared for 30 seconds. The volume of $\mathrm{NaOH}$ used was recorded and this step was repeated for three times for each sample. The content of the TTA in the sample was determined based on the following equation:

$$
\text { TTA }(\%)=\left(V_{\mathrm{NaOH}} \times N_{\mathrm{NaOH}} \times 0.064 \times 100\right) / V_{\text {sample }}
$$

\subsection{Proximate Analysis of Juice}

Analyses method for determination of moisture, ash, protein, fat and carbohydate content are based on AOAC (2000).

\subsubsection{Moisture Content}

About $1.5 \mathrm{~g}$ sample was weighed using analytical balance (Mettler Toledo, Switzerland) prior to drying the samples in the oven at $105^{\circ} \mathrm{C}$ for overnight. Samples were then left to cool in the desiccator and the samples were reweighed until it reached a consistent weight. Moisture content was calculated in percentage based on wet weight basis.

\subsubsection{Ash Content}

About $5 \mathrm{~g}$ sample was placed in crucibles and the sample was ashed in a furnace (Carbolite, $U K$ ) at $550{ }^{\circ} \mathrm{C}$ for overnight. Samples were then left to cool in the desiccator and the samples were reweighed until reached a consistent weight. Total ash content was calculated in percentage based on initial sample weight.

\subsubsection{Protein Content}

About $4 \mathrm{~g}$ sample was weighed and placed in the digestive tube. About $7 \mathrm{~g} \mathrm{~K}_{2} \mathrm{SO}_{4}, 0.8 \mathrm{~g} \mathrm{CuSO}_{4}$ and $12 \mathrm{ml}$ $\mathrm{H}_{2} \mathrm{SO}_{4}$ (catalyst) were added into the sample as well. The sample was then heated at $420{ }^{\circ} \mathrm{C}$ for 60 minutes in the digestive unit (Foss, Sweeden). Sample mixture was left to cool and $75 \mathrm{ml}$ of distilled water were added into the digestive tube prior to the distillation process. A total of $25 \mathrm{ml}$ of boric acid (4\%) was added into the conical flask. The distillation process started with the addition of $50 \mathrm{ml} \mathrm{NaOH}$ into the distillation unit (Foss, Sweeden). The boric acid was then titrated with $0.2 \mathrm{~N} \mathrm{HCl}$ until the the original color of boric acid was obtained. The percentage of protein content was determined based on following equation:

$$
\text { Protein }(\%)=\left[\left(\text { Volume }_{\text {blank }} \times \text { Weight }_{\text {sample }} \times 14.007\right) / \text { Volume }_{H C l} \times 10\right] \times 6.25
$$

\subsubsection{Fat Content}

About $5 \mathrm{~g}$ of sample was placed into the ceramic cup and weighed using analytical balance. About 2-3 spatulas of Celite $545^{\circledR}$ were added into samples and were dried over hot water bath for two hours. Samples were then mixed with 2-3 spatulas of $\mathrm{Na}_{2} \mathrm{SO}_{4}$ before been transferred into the thimbles. The thimbles were placed in the fat extractor system (Foss, Sweeden) and $70 \mathrm{ml}$ petroleum ether $(40 \%-60 \%)$ was added into the extraction cups before they were placed in the fat extractor system. When the extraction process finished, extraction cups were dried in the oven at $100{ }^{\circ} \mathrm{C}$ for 15 minutes. The extraction cups were left to cool in the desiccator and they were reweighed until consistent weight has been reached. The fat content was calculated in percentage based on initial sample weight. 


\subsubsection{Carbohydrate and Calorie Content}

Differential method has been used to determine the carbohydrate content in the sample while calorie content was determined according to Recommended Dietary Allowance (RDA) calculation:

$$
\begin{gathered}
\text { Total carbohydrate }=100 \%-(\text { Moisture } \%+\text { Ash } \%+\text { Protein } \%+\text { fat } \%) \\
\text { Calorie }(\mathrm{kcal} / 100 \mathrm{~g})=(\text { Protein } \% \times 4)+(\text { Fat } \% \times 9)+(\text { Carbohydrate } \% \times 4)
\end{gathered}
$$

\subsection{Determination of Juice Antioxidant Content}

\subsubsection{Total Polyphenol Content (TPC) Analysis}

TPC value of the juice was determined using spectrophotometer (Secomam, France) based on method by Singleton, Orthofer and Lamuela-Raventos (1999) with a slight modification. About $0.5 \mathrm{ml}$ of diluted sample was mixed with $2.5 \mathrm{ml}$ diluted Folin-Ciocalteu reagent (1:10). In interval time of 4-8 minutes, 2 ml saturated $\mathrm{NaCO}_{2}$ solution $(75 \mathrm{~g} / \mathrm{L})$ was added into the mixture prior to 2 hours of incubation in the dark at room temperature. The absorbance of the sample was measured at $760 \mathrm{~nm}$ and was compared to gallic acid serial dilution $(0.2-1 \mathrm{mM})$ by using standard curve. The value was calculated in $\mathrm{mg}$ of gallic acid equivalents (GAEs)/100 ml.

\subsubsection{Total Monomeric Antocyanin (TMA) Analysis}

The method was based on Lee, Durst, and Wrolstad (2005). About $1 \mathrm{ml}$ of liquid sample (1:10) was poured into a flask containing $25 \mathrm{ml} \mathrm{pH} 4.5$ buffer solution (this mixture was stable for 4 hours at room temperature). Same thing was done on a flask containing $\mathrm{pH} 1.0$ buffer solution and absorbance for both $\mathrm{pH}$ solutions was taken at $510 \mathrm{~nm}$ and $700 \mathrm{~nm}$. The value of TMA was determined by using below calculation:

$$
T M A(\mathrm{mg} \mathrm{C} 3 \mathrm{G} / \mathrm{L})=(\Delta A / \varepsilon L) \times M W \times 10^{3} \times D F
$$

Where, $A$ is absorbance difference, $\varepsilon$ is cyanidine-3-glucoside molar absorbance, $L$ is cell path length $M W$ is anthocyanin molecular weight, and $D F$ is dilution factor.

\subsubsection{Antioxidant Capacity by Trolox Equivalents (TEAC) Analysis}

The TEAC value was estimated using 2,2-azinobis-3-ethyl-benzothiazoline-6-sulfonic acid (ABTS) reagent assay, based on method by Thaipong et al. (2006). $7 \mathrm{mM}$ ABTS radical cation stock solution (solution A) and $2.45 \mathrm{mM}$ potassium persulfate $\left(\mathrm{K}_{8} \mathrm{~S}_{2} \mathrm{O}_{8}\right)$ stock solution (solution $\mathrm{B}$ ) were prepared and then were mixed based on 1:1 ratio to be used as working solution. The working solution was allowed to stand in the dark at room temperature for 12-16 hours before it was diluted to an absorbance of 1.1 [A] at $734 \mathrm{~nm}$. About $0.2 \mathrm{ml}$ sample aliquot was diluted with $3.8 \mathrm{ml}$ ABTS radical cation working solution prior to 2 hours incubation in the dark. Absorbance of the sample mixture was measured and was compared with Trolox serial dilution $(0-300 \mu \mathrm{M})$ standard curve. Result was reported in $\mu \mathrm{M}$ Trolox Equivalent (TE) $/ \mathrm{g}$.

\subsubsection{Antioxidant Capacity by 2,2-Diphenyl-1-Picrylhydrazyl Assay (DPPH) Analysis}

Another antioxidant capacity value was estimated by 2,2-diphenyl-1-picrylhydrazylassay (DPPH) assay. About $200 \mu \mathrm{l}$ sample was mixed with $0.1 \mathrm{mM}$ DPPH stock solution which was previously prepared by dissolving the DPPH powder in methanol to an absorbance $0.70 \pm 0.01$ at $516 \mathrm{~nm}$. The absorption of the mixture was measured after 30 minutes against blank solution (Thaipong et al., 2006). Percentage of antiradical action toward DPPH was estimated by the difference in absorbance with or without the sample (control).

\subsection{Polyphenols Compounds Determination by High-Performance Liquid Chromatography (HPLC)}

Reverse phase HPLC with photodiode array detection (DAD) was used to characterize the polyphenols compounds based on their Ultra-violet (UV) spectra. This method was based on Abad-Garc'ia et al. (2007) with some modification. Eight polyphenols compounds analyzed were consisted of hydroxybenzoic acid (gallic acid and ellagic acid), hyroxycinnamic acid (chlorogenic acid and p-coumaric acid), flavan-3-ol (catechin, epicatechin, and procyanidin B2) and antocyanidin (kuromanin chloride). All polyphenol standard solutions (ranging from 25 to $250 \mu \mathrm{g} / \mathrm{ml}$ ) were prepared in methanol and all were stored at $4{ }^{\circ} \mathrm{C}$ in darkness. Chromatographic analysis was performed by HPLC (Waters, USA), equipped with a DAD detector, and controlled by Empower software. An Atlantis C18 $(150 \times 4.6 \mathrm{~mm}$, i.d., $5 \mu \mathrm{m})$ column with mobile phase A (acetic acid-water, 0.5:99.5, v/v) and B (methanol) were used. The applied elution conditions was in gradient mode, with flow rate of $1.0 \mathrm{ml} / \mathrm{min}$ and injection volume of $10 \mu \mathrm{l}$. Hydroxybenzoic acids were monitored and quantified at $254 \mathrm{~nm}$ while flavan-3-ols and hydroxycinnamic acids were monitored at $280 \mathrm{~nm}$ and $320 \mathrm{~nm}$, respectively. 


\section{Results and Discussions}

\subsection{Physicochemical Characteristic of TP 3 in $1^{\text {TM }}$ Fruit Juice}

The $\mathrm{pH}$ value of the juice is important to be measured. It represents the degree of acidity and alkalinity of a substance. TP 3 in $1^{\mathrm{TM}}$ juice has low $\mathrm{pH}$ value of 3.69 (Table 1). This indicated that the juice was in acidic condition and suitable to be served as ready-to-drink (RTD) beverages (Malaysian Food Act 1983 and Food Regulations 1985). In beverage industry, the addition of organic acid into commercial juice was intended to lower the original $\mathrm{pH}$ of the juices (McLellan \& Padilla-Zakour, 2007). However, in preparation of TP 3 in $1^{\mathrm{TM}}$ juice there was no addition of organic acid into it. Despite of that, pathogens such as Escherichia coli (O157: H7), Salmonella sp., and parasitic protozoa such as Cryptosporidium parvum can still reproduce in juices having $\mathrm{pH}$ less than 4.6 (FDA, 2016). They are not only shortening product shelf life but also can cause food-borne illnesses and death (Ashurst \& Hargitt, 2009). Therefore, pasteurisation treatment process is a must to be carried out properly in all beverages produced. Recent studies have found that, the lower the $\mathrm{pH}$ of fruit juices, the greater the heat effect given to the microorganisms, especially in terms of pressure and radiation levels (Roller, 2003).

Table 1. Physicochemical characteristics of TP 3 in $1^{\mathrm{TM}}$ juice

\begin{tabular}{ll}
\hline Parameters & Value \\
\hline $\mathrm{pH}$ & $3.69 \pm 0.01$ \\
Total soluble solid ( ${ }^{\circ}$ Brix $)$ & $8.1 \pm 0.00$ \\
Colour $(\mathrm{L})$ & $33.25 \pm 0.03$ \\
$\quad(\mathrm{a})$ & $3.16 \pm 0.02$ \\
$\quad(\mathrm{~b})$ & $-4.63 \pm 0.02$ \\
Vitamin C (mg/100 ml) & $4.0 \pm 0.00$ \\
Total sugar $(\mathrm{g} / 100 \mathrm{ml})$ & $10.92 \pm 1.31$ \\
Titratable acidity $(\%)$ & $0.44 \pm 0.02$ \\
\hline
\end{tabular}

Note. Results were reported in average \pm standard deviation of 6 replicates.

Measurement of food color is usually performed for quality control purposes. The value L of TP 3 in $1^{\mathrm{TM}}$ juice was 33.25 while $a$ and $b$ values were 3.16 and -4.63 , respectively. Colour of the juice was highly depending on the types of the fruit that contained in the mixture. Manach, Scalbert, Morand, Remesy, and Jimenez (2004) has reported that the value of polyphenol content was in line with the colour brightness and polyphenol content will increase when the fruit is matured or cooked. Storage condition and time can also cause colour changes on food product. At the beginning of the storage period, the brightness color of the juice will increases but then decreases over the period of storage. This condition was normally caused by non enzymatic browning reaction (Bhattacherjee, Tandon, Dikshit, \& Kumar, 2011).

The main soluble solid in fruit juices normally consisted of sugar. Other than that, organic compounds, amino acids and pectin that are present in fruit juice also can be considered as soluble solids (Garner, Crisosto, Wiley, \& Crisosto, 2013). In this study, corresponding value for total soluble solids (TSS) of TP 3 in $1^{\mathrm{TM}}$ juice was $8.1^{\circ}$ Brix. According to Malaysian Food Act 1983 and Food Regulations 1985, the amount of soluble solids for fruit juices shall not be less than $8 \mathrm{~g} / 100 \mathrm{ml}$ at $20^{\circ} \mathrm{C}$. At $20^{\circ} \mathrm{C}, 1{ }^{\circ}$ Brix usually coincides with $1 \mathrm{~g}$ of sucrose in every $100 \mathrm{ml}$ of solution (ICUMSA, 2015). This mean TP 3 in $1^{\mathrm{TM}}$ juice can still be consider as fruit juice because it contained $8.1 \mathrm{~g} / 100 \mathrm{ml}$ of TSS at $20^{\circ} \mathrm{C}$.

Each $100 \mathrm{ml}$ of the juice also contained $10.92 \%$ total sugar, $4.0 \mathrm{mg}$ vitamin $\mathrm{C}$ and $0.44 \%$ titratable citric acid. This value complies with the Malaysian Food Act 1983 and Food Regulations 1985, which outlines that the acidity of fruit juices should be lower than $3.5 \%$ citric acid. The value of titratable acidity (TTA) was measured to determine the degree of acidity of fruit juices caused by acid production by polysaccharides, pectic materials, and uric acid (Durrani, Ayub, Muhammad, \& Ali, 2010; Yadav, Tripathi, \& Jha, 2013). According to Hussain, Zeb, Shakir, and Sattar Shah (2008), oxidation of reducing sugar during maturity process can contribute to the increase of fruit acidity. In food analysis, the value of TTA has an indirect relationship with the $\mathrm{pH}$ value (AOAC, 2007). Each of these values was determined separately in different ways and each has its own effect on the quality of the food where TTA can describe the effect of acid on taste of the food better than $\mathrm{pH}$ (Gardner, 1996). However, correlation analysis of $\mathrm{pH}$ and TTA values obtained in this study showed no significant 
correlation $(\mathrm{r}=-0.210)(\mathrm{p}>0.01)$ between them. TTA value can also be used to determine the rate of ripening of fruit (Perkins-Veazie \& Collins, 2002).

The previous study found that vitamin $\mathrm{C}$ or ascorbic acid content decreased when there was a change in temperature during process of pasteurisation and the amount of sugar increased during the storage period of the juice (Mgaya-Kilima, Remberg, Chove, \& Wicklund, 2014). It cannot be denied that there was a change in temperature throughout the processing and storing of the juice even though the precaution measures have been taken. The results for total sugar and soluble solids content of TP 3 in $1^{\mathrm{TM}}$ juice showed a strong and significant positive correlation $(\mathrm{p}<0.01)$. This clearly indicated that the amount of soluble solids in the juice of the juice was contributed by the sugar content. The correlation value between total sugar and soluble solids was $r=0.892$.

\subsection{Proximate Composition of TP 3 in $1^{T M}$ Fruit Juice}

The moisture content in food or drink is the same as the water content, where water is one of the important macronutrients in the daily diet. According to FDA (2016), high water content food or drink normally contains $85 \%$ or more moisture value. Table 2 showed TP 3 in $1^{\mathrm{TM}}$ juice contained $89.38 \%$ water. This moisture value is normal and within the same range of most freshly made mixed juice product (Mgaya-Kilima et al., 2014; Akusu, Kiin-Kibari, \& Ebere, 2016). The total ash content of this juice was $0.15 \%$. Ash content in food can be referring to the residue of inorganic substances such as minerals in a food (Pomeranz \& Meloan, 1994). The higher ash content indicates higher mineral content (Monti, Virgilio, \& Venturi, 2008).

Table 2. Proximate proportion of TP 3 in $1^{\mathrm{TM}}$ juice

\begin{tabular}{ll}
\hline Parameters & Value \\
\hline Moisture (\%) & $89.38 \pm 0.35$ \\
Total ash (\%) & $0.15 \pm 0.02$ \\
Protein (\%) & $0.16 \pm 0.02$ \\
Fat (\%) & $\mathrm{n} / \mathrm{a}$ \\
Total carbohydrate (\%) & $10.31 \pm 0.36$ \\
Calorie (kcal) & $41.86 \pm 1.50$ \\
\hline
\end{tabular}

Note. Results were reported in average \pm standard deviation of 6 replicates.

Result showed that fat content was absence in this juice. This may be due to the type of fruits used in the juice formulation, when there was absolutely no fat or the content was not significant to be detected by the Soxhlet method. The Soxhlet method has a lower limit detection of $0.1 \%$, in which food samples that have lower than $0.1 \%$ fat cannot be determined by this tool (Murray-Brown Laboratories, 2014). This also indicated that the combination of these fruit juices was very healthy because it has very low fat content. TP 3 in $1^{\mathrm{TM}}$ juice has $0.16 \%$ protein and $10.31 \%$ of total carbohydrates. The juice was also low in calories, which contained only 42 kcal per $100 \mathrm{ml}$ and suitable to be included in a daily diet. Calories in TP 3 in $1^{\mathrm{TM}}$ juice was mainly contributed by carbohydrate and protein contents. O. K. Ahmed and S. E. D. Ahmed (2014) reported that matured fruits were usually sweeter. Therefore, the level of fruit sweetness can be measured based on the content of sugar or the amount of carbohydrate. The value of carbohydrates in a diet usually not only consisted of sugar content but also dietary fiber. Natural sugar in fresh fruits is commonly known as fructose, a type of simple sugar monosaccharide (Rippe \& Angelopoulos, 2015) while dietary fibers can also be categorized as complex polysaccharides (Eastwood \& Kritchevsky, 2005). Generally, some nutrients such as protein, fat and fiber will be slightly lower in fruit juice compared to its fresh fruit because these nutrients were reduced during the processing of the fruit juice (Mercola 2014). Fortification and enrichment of any nutrient can be carried out if needed.

\subsection{Total Phenolic Content and Antioxidant Capacity of TP 3 in $1^{T M}$ Fruit Juice}

Generally, it was known that total phenolic content are highly correlated with antioxidant activity and bioavailability of polyphenols (Manach, Williamson, Morad, Scalbert, \& Remesy, 2005). In this study, two phenolic tests were carried out on the juice which were total phenolic content (TPC) and total monomeric anthocyanin (TMA). In general, TPC quantifies total amount phenol group including mono-phenol, phenol, tri-phenol and polyphenol compounds (Rana, 2014) while anthocyanin only quantities polyphenols under the subgroups of flavonoids. Therefore, both tests were done to get extra information about the possible difference between phenolic and anthocyanin value. Table 3 shows TMA value for TP 3 in $1^{\mathrm{TM}}$ juice was $12.94 \mathrm{mg}$ cyanidin-3-glucoside (C3G)/100 ml. This present study have the same outcome with study by Burin et al. (2010) 
who reported that the intensity of the red color (a) in the fruit juice indicated of higher anthocyanin content in it. TPC values in fruit juices can be divided into several groups according to certain values. TPC values less than $500 \mathrm{mg}$ GAE$/ 100 \mathrm{ml}$ can be categorized as low while moderate TPC values range were ranging from 500 to $2000 \mathrm{mg} \mathrm{GAE} / 100 \mathrm{ml}$. The TPC value is considered high if the content exceeds $2000 \mathrm{mg}$ GAE$/ 100 \mathrm{ml}$ (Ikram et al., 2009). Table 3 shows TPC value of TP 3 in $1^{\mathrm{TM}}$ juice, which was $609 \mathrm{mg}$ gallic acid equivalent (GAE)/100 $\mathrm{ml}$. Reddy, Gupta, Jacob, Khan, and Ferreira (2007) found that TPC value of single fruit was much more lower compared to mixed juice in this study. The latter study reported that Indian pomegranate and roselle contained $219 \mathrm{mg} \mathrm{GAE} / 100 \mathrm{~g}$ and $374 \mathrm{mg} \mathrm{GAE} / 100 \mathrm{~g}$, respectively. However, previous study (Ikram et al., 2009) reported that Malaysian guava fruit has much higher TPC value, which is $1394.94 \mathrm{mg}$ GAE/100 g. Manach et al. (2004) reported there were many factors that were likely influenced the phenolic content. Some of the factors were the time of fruit was harvested, the fruit ripening state, the environmental factor and the physical factors during the processing and storage operation. Environmental factors such as soil and weather conditions have the most significant effect on polyphenol content. Ghasemzadeh, Jaafar, Rahmat, Megat Wahab, and Abd Halim (2010) found that exposure to sunlight affects almost all types of flavonoids. Price, Breen, Valladao, and Watson (1995) reported that differences in flavonol concentration exist among several fruit seeds on the same tree. This was due to exposure to unbalanced sunlight on all part of the tree which showed a variance in their polyphenol content. The total antioxidant (free radical scavenging) activity of fruits was mainly attributed to the additive and synergistic effects of inherent phytochemicals notably, the phenolic compounds (Liu, 2003; Cartea, Francisco, Soengas, \& Velasco, 2011).

Table 3. Antioxidant activity of TP 3 in $1^{\mathrm{TM}}$ juice

\begin{tabular}{ll}
\hline Assays & Value \\
\hline Total phenolic content $(\mathrm{mg} \mathrm{GAE} / 100 \mathrm{ml})$ & $609.00 \pm 22.63$ \\
Total monomer anthocyanin $(\mathrm{mg} \mathrm{C} 3 \mathrm{G} / 100 \mathrm{ml})$ & $12.94 \pm 0.82$ \\
DPPH $(\%)$ & $88.90 \pm 0.72$ \\
ABTS $(\mu \mathrm{M} \mathrm{TE} / \mathrm{ml})$ & $472.44 \pm 11.09$ \\
\hline
\end{tabular}

Note. Results were reported in average \pm standard deviation of 6 replicates.

The First International Congress on Antioxidant Method, in June 2004, has recommended TPC test and at least two different antioxidant tests to be carried out in order to confirm the final results of antioxidant activity in the food samples (Prior, $\mathrm{Wu}, \&$ Schaich, 2005). Antioxidant value obtained through DPPH and ABTS tests in TP 3 in $1^{\mathrm{TM}}$ juice were $88.90 \%$ and $472.44 \mu \mathrm{M}$ Trolox equivalent (TE) per ml, respectively. Fruit juices normally have medium antioxidant capacity but have higher value for phenolic compounds, carotenoids and vitamin $\mathrm{C}$ (Ramadan-Hassanein, 2008). Yang et al. (2012) also used the same test (DPPH and ABTS) in their study because both tests had a good correlation with TPC. The present study also reported positive correlation between TPC and both reported antioxidant assays $(r=0.808$ and $r=0.826$, respectively). The DPPH test was easy to use and widely used to determine the activity of phenolic and antioxidant of pigmented compounds (Cai, Sun, \& Corke, 2003) while ABTS tests were found to be suitable for samples in acidic condition and contained hydrophilic components (Fu et al., 2011). However, these antioxidant tests are very sensitive and need to be carried out with care. Precautions should be taken such as not exposing reagents and samples to direct lights as well as using fresh solutions each time during the analysis. It is important to run multiple antioxidant test in order to get better estimation of antioxidant capacity and to substantiate in vitro results with clinical studies (Seeram et al., 2008). A slight difference in the method of antioxidant used may have caused variability in the results. Factor such as pasteurisation condition used in preparing juice may also affect the changes of the antioxidant capacity of juice. Other than that, temperature variation during sample incubation and different specification of spectrophotometer used can also leads to significant internal variability (Hernández, Fraga, A. I. Jimenez, F. Jimenez, \& Arias, 1999). Keisha and Jose (2009) suggested that the value of plant antioxidant activity could be increased by delaying the harvesting process at maturity level. This was due to their study showed linear relationship between antioxidant activity and maturity stage $(\mathrm{r}=0.59)$ of the fruits.

\subsection{Polyphenol Compounds in TP 3 in $1^{\text {TM }}$ Fruit Juice}

Several polyphenol compounds which were present in pomegranate, guava and roselle calyx juice extract from previous research were studied. Eight types of polyphenols were selected to be determined in TP 3 in $1^{\mathrm{TM}}$ juice. In this study, ellagic acid (EA) was the highest component in the juice with a value of $633.73 \mathrm{mg} / 100 \mathrm{ml}$ (Table 
4). The results also indicated that individual polyphenol such as procyanidin B2 $(375.99 \mathrm{mg})$, chlorogenic acid (327.59 mg), epicatechin $(291.10 \mathrm{mg})$, gallic acid $(195.39 \mathrm{mg})$ and catechin $(117.22 \mathrm{mg}$ ) were abundantly found in each $100 \mathrm{ml}$ juice. In addition, p-coumaric acid $(0.13 \mathrm{mg})$ and kuromanin chloride $(15.19 \mathrm{mg})$ were also present in every $100 \mathrm{ml}$ TP 3 in $1^{\mathrm{TM}}$ juice. EA and chlorogenic acid was found to be the most predominant and common polyphenol in this fruit juice. EA is a main component of plant cell wall. It is a dimeric derivative of gallic acid, occurs in fruits (fresh and processed) and nuts in either its free form, as EA-glycosides, or bound as ellagitannins (Amakura, Okada, Tsuji, \& Tonogai, 2000; Clifford \& Scalbert, 2000). Medicinally, EA was used to prevent cancer, treat viral and bacterial infections (WebMD, 2017). Previous study (Seeram et al., 2005), has used pomegranate juice as the main supplement for EA in his human study. Chlorogenic acid was found abundantly in fruit cultivar of western countries but not in tropical fruit cultivar. It has been reported to exist in varieties of apples and berries (Svedstrom, Vuorela, Kostiainen, Laakso, \& Hiltunen, 2006; Ceymann et al., 2012). The wide range of potential health benefits of chlorogenic acid has been reported including its anti-diabetic, anti-carcinogenic, anti-inflammatory and anti-obesity impacts (N. Tajik, M. Tajik, Mack, \& Enck, 2017). Procyanidin B2 was normally found in red color juices such as pomegranate and roselle juices. As such procyanidin $\mathrm{B} 2$ is normally a reference compound for anthocyanidin.

Table 4. Targeted polyohenol compounds in TP 3 in $1^{\mathrm{TM}}$ juice

\begin{tabular}{ll}
\hline Compounds & Value $(\mathrm{mg} / 100 \mathrm{ml})$ \\
\hline Gallic acid (GA) & $195.39 \pm 13.35$ \\
Ellagic acid (EA) & $633.73 \pm 80.44$ \\
Catechin & $117.22 \pm 57.22$ \\
Epicatechin & $291.10 \pm 70.63$ \\
P-coumaric acid & $0.13 \pm 0.01$ \\
Chlorogenic acid & $327.59 \pm 73.43$ \\
Procyanidin B2 & $375.99 \pm 99.44$ \\
Kuromanin chloride & $15.19 \pm 6.55$ \\
\hline
\end{tabular}

Note. Results were reported in average \pm standard deviation of 6 replicates.

\section{Conclusion}

In conclusion, this present study reported that TP 3 in $1^{\mathrm{TM}}$ fruit juice have acceptable physical properties and contained significant amount of phenolic and antioxidant content. Pomegranate, guava and roselle juice individually contained various nutrient and a combination of these three fruit juices may provide beneficial activity towards health. The juice is expected to be commercialized to be one of the healthy choice drinks that everyone can enjoy.

\section{Acknowledgements}

This study was part of the e-Science Fund grant (06-01-02-SF0764) funded by Ministry of Science, Technology \& Innovation (MOSTI) Malaysia. The authors would like to acknowledge the Faculty of Health Sciences, Faculty of Science and Technology and Centre for Research and Innovation Management (CRIM) UKM for their support in this study.

\section{References}

Abad-Garcia, B., Berrueta, L. A., Lopez-Marquez, D. M., Crespo-Ferrer, I., Gallo, B., \& Vicente, F. (2007). Optimization and validation of a methodology based on solvent extraction and liquid chromatography for the simultaneous determination of several polyphenolic families in fruit juices. Journal of Chromatography A, 1154, 87-96. https://doi.org/10.1016/j.chroma.2007.03.023

Ahmed, O. K., \& Ahmed, S. E. D. (2014). Determination of optimum maturity index of mango fruits (Mangifera indica L.) in Darfur. Agriculture and Biology Journal of North America, 5(2), 97-103. https://doi.org/ 10.5251/abjna.2015.6.6.160.167

Akusu, O. M., Kiin-Kibari, D. B., \& Ebere, C. O. (2016). Quality characteristic of orange/pineapple fruit juice blends. American Journal of Food Scince and Technology, 4(2), 43-47. https://doi.org/10.12691/ajfst-4-2-3 
Amakura, Y., Okada, M., Tsuji, A., \& Tonogai, Y. (2000). High-performance liquid chromatography determination with photodiode array detection of ellagic acid in fresh and processed fruits. Journal of Chromatography B, 896, 87-93. https://doi.org/10.3358/shokueishi.41.206

Ashurst, P. R., \& Hargitt, R. (2009). Soft drink and fruit juice problem solved. Cambridge: Woodhead Publishing

AOAC (Association of Official Analytical Chemist). (2000). Official methods of analysis of AOAC International (17th ed.). Washington, DC: Association of Official Analytical Chemist.

Bhattacherjee, A. K., Tandon, D. K., Dikshit, A., \& Kumar, S. (2011). Effect of pasteurisation temperature on quality of aonla juice during storage. Journal of Food Science and Technology, 48(3), 269-273. https:/doi.org/10.1007/s13197-010-0171-5

Burin, V. M., Falcão, L. D., Gonzaga, L. V., Fett, R., Rosier, J. P., \& Bordignon-Luiz, M. T. (2010). Colour, phenolic content and antioxidant activity of grape juice. Ciência Tecnologia Alimentos, Campinas, 30(4), 1027-1032. https://doi.org/10.1590/S0101-20612010000400030

Cai, Y. Z., Sun, M., \& Corke, H. (2003). Antioxidant activity of betalains from plants of the Amaranthaceae. Journal of Agricultural and Food Chemistry, 51, 2288-2294. https://doi.org/10.1021/jf030045u

Cartea, M. E., Francisco, M., Soengas, P., \& Velasco, P. (2011). Phenolic compounds in Brassica vegetables. Molecules Basel Switzerland, 16(1), 251-280. https://doi.org/10.3390/molecules16010251

Ceymann, M., Arrigoni, E., Schärer, H., Bozzi, N., Anna, H., \& Richard, F. (2012). Identification of apples rich in health-promoting flavan-3-ols and phenolic acids by measuring the polyphenol profile. Journal of Food Composition and Analysis, 26, 128-135. https://doi.org/10.1016/j.jfca.2011.12.002

Clifford, M. N., \& Scalbert, A. (2000). Ellagitannins-Nature, occurrence and dietary burden. Journal of Science and Food Agriculture, 80, 1118-25. https://doi.org/10.1002/(SICI)1097-0010(20000515)80:7<1118::AIDJSFA $570>3.0 . C O ; 2-9$

Durrani, Y., Ayub, M., Muhammad, A., \& Ali, A. (2010). Physicochemical response of apple pulp to chemical preservatives and antioxidant during storage. Internet Journal of Food Safety, 12, 20-28. Retrieved from http://www.internetjfs.org/articles/ijfsv12-4.pdf

Eastwood, M., \& Kritchevsky, D. (2005). Dietary fiber: How did we get where we are? Annual Reviews on Nutrition, 25, 1-8. https://doi.org/10.1146/annurev.nutr.25.121304.131658

Fabro, M. A., Milanesio, H. V., Robert, L. M., Speranza, J. L., Murphy, M., Rodríguez, G., \& Castañeda, R. (2006). Determination of acidity in whole raw milk: Comparison of results obtained from two different analytical methods. Journal of Dairy Science, 89, 859-861 https://doi.org/10.3168/jds.S0022-0302(06) 72149-X

FDA (Food Department of Agriculture of USDA). (2016). Guidance for industry: Juice HACCP hazards and controls guidance (1st ed.). Final Guidance. Retrieved from https://www.fda.gov/food/guidanceregulation/ guidancedocumentsregulatoryinformation/juice/ucm072557.htm

Fernández-Salguero, J., Gómez, R., \& Carmona, M. A. (1993). Water activity in selected high-moisture foods. Journal of Food Composition Analysis, 6, 364-369. https://doi.org/10.1006/jfca.1993.1040

FAO (Food and Agriculture Organization of the United Nations). (1998). Food energy-methods of analysis and conversion factor. Rome, Italy: Food and Agriculture Organization of the United Nations. Retrieved from http://www.fao.org/uploads/media/FAO_2003_Food_Energy_02.pdf

Fu, L., Xu, B. T., Xu, X. R., Gan, R. Y., Zhang, Y., Xia, E. Q., \& Li, H. B. (2011). Antioxidant capacities and total phenolic contents of 62 fruits. Food Chemistry, 129, 345-350. https://doi.org/10.1016/j.foodchem. 2011.04.079

Gardner, W. H. (1996). Food Acidulants. New York, Allied Chemical.

Garner, D., Crisosto, C. H., Wiley, P., \& Crisosto, G. M. (2013). Measurement of total soluble solid (pp. 11-55). Retrieved from http://fruitandnuteducation.ucdavis.edu/files/162033.pdf

Ghasemzadeh, A., Jaafar, H. Z. E., Rahmat, A., Megat Wahab, P. E., \& Abd Halim, M. R. (2010). Effect of different light intensities on total phenolics and flavonoids synthesis and anti-oxidant activities in young ginger varieties (Zingiber officinale Roscoe). International Journal of Molecular Science, 11(10), 3885-3897. https://doi.org/10.3390/ijms11103885 
Hernandez, O. M., Fraga, J. M. G., Jimenez, A. I., Jimenez, F., \& Arias, J. J. (1999). Characterization of honey from the Canary Islands: Determination of the mineral content by atomic absorption spectrophotometry. Food Chemistry, 93, 449-458. https://doi.org/ 10.1016/j.foodchem.2004.10.03

Hussain, I., Zeb, A., Shakir, I., \& Sattar Shah, A. (2008). Combine effect of potassium sorbate and sodium benzoate on individual and blended juices of apricot and apple fruits grown in Azad Jammu and Kashmir. Pakistan Journal of Nutrition, 7, 181-185. https://doi.org/10.3923/pjn.2008.181.185

Ikram, E. H .K., Eng, K. H., Mohd Jalil, A. M., Amin, I., Salma, I., Azrina, A., ... Ruzaidi Azli, M. H. (2009). Antioxidant capacity and total phenolic content of Malaysian underutilized fruits. Journal of Food Composition and Analysis, 22, 388-393. https://doi.org/ 10.1016/j.jfca.2009.04.001

ICUMSA (International Commision for Uniform Methods of Sugar Analysis). (2015). Method Book. Germany. Bartens.

Johanningsmeier, S. D., \& Harris, G. K. (2011). Pomegranate as a functional food \& nutraceutical source. Annual Revise Food Science Technology, 2, 181-201. https://doi.org/10.1146/annurev-food-030810-153709

Jurenka, J. S. (2008). Therapeutic applications of pomegranate (Punica granatum L.): A review. Alternative Medicine Review, 13, 128-44. Retrieved from http://www.altmedrev.com/publications/13/2/128.pdf

Keisha, R. C., \& José, C. J. (2009). Changes in total phenolic and monomeric anthocyanin composition and antioxidant activity of three varieties of sorrel (Hibiscus sabdariffa) during maturity. Journal of Food Composition and Analysis, 22(7-8), 663-667. https://doi.org/10.1016/j.jfca.2009.05.007

Kit, L. Y., \& Spyridon, E. P. (2004). A simple digital imaging method for measuring and analyzing color of food surfaces. Journal of Food Engineering, 61, 137-142. https://doi.org/10.1016/S0260-8774(03)00195-X

Lambert, J. D., Hong, J., Yang, G., Liao, J., \& Yang, C. S. (2005). Inhibition of carcinogenesis by polyphenols: Evidence from laboratory investigations. American Journal of Clinical Nutrition, 81, 284S-91S. Retrieved from http://ajcn.nutrition.org/content/81/1/284S.long

Lee, J., Durst, R. W., \& Wrolstad, R. E. (2005). Determination of total monomeric anthocyanin pigment content of fruit juices, beverages, natural colorants, and wines by the $\mathrm{pH}$ differential method: Collaborative study. Journal of AOAC International, 88(5), 1269-1278. https://doi.org/10.5555/jaoi.2005.88.5.1269

Liu, R. H. (2003). Health benefits of fruit and vegetables are from additive and synergistic combinations of phytochemicals. American Journal of Clinical Nutrition, 78(Suppl.), 517S-20S. Retrieved from http://ajcn.nutrition.org/content/78/3/517S.long

Malaysian Food Act 1983 and Food Regulations 1986. Food Regulations. Malaysia: MDC Publisher.

Manach, C., Scalbert, A., Morand, C., Rémésy, C., \& Jimenez, L. (2004). Polyphenols: Food sources and bioavailability. American Journal of Clinical Nutrition, 79(5), 727-47. Retrieved from http://ajcn.nutrition. org/content/79/5/727.full

Manach, C., Williamson, G., Morad, C., Scalbert, A., \& Remesy, C. (2005). Bioavailability and bioefficacy of polyphenols in humans. 1. Review of 97 bioavailability studies. American Journal of Clinical Nutrition, 81, 230S-242S. Retrieved from http://ajcn.nutrition.org/content/81/1/230S.long

McLellan, M. R., \& Padilla-Zakour, O. I. (2007). Juice processing. In D. M. Barrett, L. P. Somogyi, \& H. Ramaswamy (Eds.), Processing fruits: Science and Technology (pp. 72-95). Boca Raton: CRC Press.

Medjakovic, S., \& Jungbauer, A. (2013). Pomegranate: A fruit that ameliorates metabolic syndrome. Food Functional, 4, 19-39. https://doi.org/10.1039/c2fo30034f

Mercola, J. (2014). Juicing: How healthy is it? Retrieved November 16, 2016, from http://articles.mercola.com/ sites/articles/archive/2014/04/19/juicing-benefits.aspx

Mgaya-Kilima, B., Remberg, S. F., Chove, B. E., \& Wicklund, T. (2014). Influence of storage temperature and time on the physicochemical and bioactive properties of roselle-fruit juice blends in plastic bottle. Fruit Science and Nutrition, 2(2), 181-191. https://doi.org/10.1002/fsn3.97

Mittal, P., Gupta, V., Kaur, G., Garg, A. K., \& Singh, A. (2010). Phytochemistry and pharmacological activities of Psidium Guajava: A review. International Journal of Pharmaseutical Science and Research, 1(9), 9-19. https://doi.org/10.13040/IJPSR.0975-8232.1(9-S).9-19

Mitra, S. K., Devi, H., \& Debnath, S. (2014). Tropical and subtropical fruits and human health. Acta Horiculturae, 1024, 39-48. https://doi.org/10.17660/ActaHortic.2014.1024.2 
Monti, A., Vigilio, N. D., \& Venturi, G. (2008). Mineral composition and ash content of six major energy crops. Biomass and Bioenergy, 32(3), 216-223. https://doi.org/10.1016/j.biombioe.2007.09.012

Murray Brown Laboratory. (2014). Total fat via soxtec extraction unit by BML. Behind the Chemistry. Retrieved from http://mb-labs.com/resources/total-fat-via-soxtec-extraction-unit

Ophardt, E. C. (2003). Acid and Bases. Elmhurst College: Virtual Chem Book. Retrieved from http://chemistry.elmhurst.edu/vchembook/184ph.html

Perkins-Veazie, P., \& Collins, J. K. (2002). Quality of erect-type blackberry fruits after short intervals of controlled atmosphere storage. Postharvest Biology and Technology, 25, 235-239. https://doi.org/10.1016/ S0925-5214(02)00025-X

Pomeranz, Y., \& Meloan, E. C. (1994). Ash and Minerals. Food Analysis: Theory and Practice (3rd ed., pp. 602-624). United State: Springer. https://doi.org/10.1007/978-1-4615-6998-5

Prasongwatana, V., Woottisin, S., Sriboonlue, P., \& Kukongviriyapan, V. (2008). Uricosuric effect of Roselle (Hibiscus sabdariffa) in normal and renal-stone former subjects. Journal of Ethnopharmacology, 117(3), 491-495. https://doi.org/10.1016/j.jep.2008.02.036

Price, S. F., Breen, P. J., Valladao, M., \& Watson, B. T. (1995). Cluster sun exposure and quercetin in pinot noir grapes and wine. American Journal of Enology and Viticulture, 46, 187-194. Retrieved from http://www.ajevonline.org/content/46/2/187

Prior, L. R., Wu, X. \& Schaich, K. (2005). Standardized methods for the determination of antioxidants capacity and phenolics in foods and dietary supplements. Journal of Agriculture and Food Chemistry, 53, 4290-4302. https://doi.org/10.1021/jf0502698

Ramadan-Hassanien, M. F. (2008). Total antioxidant potential of juices, beverages and hot drinks consumed in Egypt screened by DPPH in vitro assay. Grasas y Aceites, 59(3), 254-259. https://doi.org/10.3989/gya.2008. v59.i3.516

Rana, A. (2014). What is the relation between total phenol \& total flavonoids? Retrieved December 28, 2016, from https://www.researchgate.net/post/What_is_the_relation_between_total_Phenol_total_Flavonoids

Rasheed, Z., Akhtar, N., Anbazhagan, A. N., Ramamurthy, S., Shukla, M., \& Haqqd, T. M. (2009). Polyphenolrich pomegranate fruit extract (POMx) suppresses PMACI-induced expression of pro-inflammatory cytokines by inhibiting the activation of MAP Kinases and NF- $\kappa \mathrm{B}$ in human KU812 cells. Journal of Inflammation, 6, 1-11. https://doi.org/10.1186/1476-9255-6-1

Reddy, M. K., Gupta, S. K., Jacob, M. R., Khan, S. L., \& Ferreira, D. (2007). Antioxidant, amtimalarial and antimicrobial activities ofd tannin-rich fractions, ellegitannins and phenolic acids from Punica granatum L. Plant Medicine, 73(5), 461-467. https://doi.org/10.1055/s-2007-967167

Rippe, J. M., \& Angelopoulos, T. J. (2015). Fructose-containing sugars and cardiovascular disease. Advances in Nutrition, 6(4), 430-439. https://doi.org/10.3945/an.114.008177

Rokiah, M. Y., Fadhillah, L., Zaitun, Y., \& Asmah, R. (2003) Potential health benefits of tropical fruits. Poceedings of the International Tropical Fruit Network Seminar on Tropical Fruit Production, TFNet.

Roller, S. (2003). Natural antimicrobials for the minimal processing of foods (1st ed., Chapter 10, p. 201). Elsevier: Woodhead Publishing.

Seeram, N. P., Adams, L. S., Henning, S. M., Niu, Y., Zhang, Y., Nair, M. G., \& Heber, D. (2005). In vitro antiproliferative, apoptotic and antioxidant activities of punicalagin, ellagic acid and a total pomegranate tannin extract are enhanced in combination with other polyphenols as found in pomegranate juice. Journal of Nutritional Biochemistry, 16, 360-367. https://doi.org/10.1016/j.jnutbio.2005.01.006

Seeram, N. P., Aviram, M., Zhang, Y., Henning, S. M., Feng, L., Dreher, M., \& Heber, D. (2008). Comparison of antioxidant potency of commonly consumed polyphenols-rich beverages in United States. Journal of Agricultural and Food Chemistry, 56, 1415-1422. https://doi.org/10.1021/jf073035s

Singleton, V. L., Orthofer, R., \& Lamuela-Raventos, R. M. (1999). Analysis of total phenols and other oxidation substrates and antioxidants by means of Folin-Ciocalteu reagent. Methods of Enzymology, 299, 152-178. https://doi.org/10.1016/S0076-6879(99)99017-1

Svedström, U., Vuorela, H., Kostiainen, R., Laakso, I., \& Hiltunen, R. (2006). Fractionation of polyphenols in hawthorn into polymeric procyanidins, phenolic acids and flavonoids prior to high-performance liquid 
chromatographic analysis. Journal of Chromatography A, 1112, 103-111. https://doi.org/10.1016/j.chroma. 2005.12.080

Tajik, N., Tajik, M., Mack, I., \& Enck, P. (2017). The potential effects of chlorogenic acid, the main phenolic components in coffee, on health: A comprehensive review of the literature. European Journal of Nutrition, 56(7), 2215-2244. https://doi.org/10.1007/s00394-017-1379-1

Thaipong, K., Boonprakob, U., Crosby, K., Cisneros-Zevallos, L., \& Byrne, H. D. (2006). Comparison of ABTS, DPPH, FRAP, and ORAC assays for estimating antioxidant activity from guava fruit extracts. Journal of Food Composition and Analysis, 19, 669-675. https://doi.org/10.1016/j.jfca.2006.01.003

WebMD. (2017). Ellagic Acid. Retrieved from https://www.webmd.com/vitamins-supplements/ingredientmono1074-ellagic\%20acid.aspx?activeingredientid=1074\&activeingredientname=ellagic\%20acid

Yadav, R., Tripathi, A. D., \& Jha, A. (2013). Effect of storage time on the physicochemical properties and sensory attributes of Aloe vera ready-to-serve (RTS) beverage. International Journal of Food, Nutrition and Public Health, 6, 173-192.

Yang, L., Gou, Y., Zhao, T., Zhao, J., Li, F., Zhang, B., \& Wu, X. (2012). Antioxidant capacity of extracts from calyx fruits of Roselle (Hibiscus sabdariffa L.). African Journal of Biotechnology, 11(17), 4063-4068. https://doi.org/10.5897/AJB11.2227

\section{Copyrights}

Copyright for this article is retained by the author(s), with first publication rights granted to the journal.

This is an open-access article distributed under the terms and conditions of the Creative Commons Attribution license (http://creativecommons.org/licenses/by/4.0/). 